\title{
Identification of Nuclear Receptor targets by chromatin immunoprecipitation in fatty liver
}

\author{
Natalia Becares ${ }^{1^{\star}}$ and Inés Pineda-Torra ${ }^{1^{\star}}$
}

${ }^{1}$ Centre for Clinical Pharmacology, Division of Medicine, University College of London, 5 University Street, London, WC1E 6JF, United Kingdom.

"Correspondence should be addressed to:

Inés Pineda-Torra, Centre for Clinical Pharmacology, Division of Medicine, University College London, London WC1E 6JF, UK. Phone: +44 (0)20 76796535.

E-mail: i.torra@ucl.ac.uk

\section{Summary}

Chromatin Immunoprecipitation (ChIP) assays allow for the study of protein-DNA interactions in physiological contexts. Briefly, ChIPs consist of the purification and enrichment of a protein of interest together with its associated chromatin, and its later identification. Hence, this technique proves to be particularly useful when assessing novel target genes for nuclear receptors. In the field of metabolic liver diseases, the validation of putative nuclear receptor targets is key for furthering the development of nuclear receptor modulators as therapeutic compounds. In this chapter, the protocol described has been optimised for ChIP on mouse fatty (steatotic) livers. Thanks to the use of a "two-step" (double) crosslinking method, this protocol can also be used for the study of other proteins with weaker interactions or that are present in large complexes, such as cofactors.

\section{Key words}

Nuclear receptors, chromatin immunoprecipitation, crosslinking, fatty liver, mouse model 


\section{Introduction}

One of the fundamental themes in the study of Nuclear Receptor biology has been the identification of bona fide target genes, ie. genes that are directly regulated by this class of transcription factors. Due to the nature of these transcription factors, which are sensitive to a vast variety of stimuli and subject to strict regulations under changing physiological and environmental conditions (1), new target genes are being constantly uncovered. Theoretical approaches to target identification, such as in silico discovery of binding sequences have proven to be highly informative (2). Nonetheless, these in silico methods carry a high risk of delivering false negative results; thus requiring that the identified putative binding sequences should always be corroborated experimentally. ChIP-based assays are a very useful tool in the study of protein-DNA interactions in vivo (3). In comparison to other in vitro techniques (i.e. electrophoretic mobility shift assays), ChIP studies allow for the investigation of these interactions in a physiological context, therefore providing a higher utility. Briefly, ChIP-based assays consist on the purification of a protein of interest together with its associated chromatin region by using specific antibodies. Once the chromatin is isolated and freed from interacting proteins, it is then analysed by different techniques depending on the downstream approach.

For non-histone proteins that have weaker affinities, such as transcription factors, previous crosslinking of DNA to proteins is usually required (X-ChIP). This crosslinking is generally performed using formaldehyde, a reversible crosslinker. However, in certain situations where crosslinking across longer intermolecular distances are needed (longer than $2 \AA$ ), such as for cofactor binding, alternative cross-linkers are needed (4). Nonetheless, this step should be taken with precaution as extreme cross-linking can lead to several downstream issues, such as sonication efficiency. After crosslinking, cells are lysed, and the chromatin is fragmented and subsequently immunoprecipitated. Thus, any DNA sequences bound to our protein of interest will co-precipitate and get enriched. Later, the DNA-protein complexes will be broken (reverse crosslink) and the DNA will be purified. Identification of purified DNA 
sequences can be performed by multiple methods, including quantitative real-time PCR or by direct sequencing (ChIP-seq).

In the field of liver biology, nuclear receptors have been proven to play a pivotal role in the regulation of lipid metabolism and homeostasis (5), as well as to act as strong modulators of inflammation and immunity (6). Subsequently, these receptors have been the target of several therapies to combat liver disease, as is the case of the peroxisome proliferator activated receptor gamma (PPARY) agonist, pioglitazone, or the specific farnesoid $X$ receptor (FXR) agonist obeticholic acid (OCA), for the treatment of Non Alcoholic Fatty Liver Disease (NAFLD) $(\mathbf{7}, 8)$. Hence, a better understanding of the specific nuclear receptor liver targets under physiological and pathological conditions is key to furthering therapeutic avenues.

When performing ChIP on tissues or cells with a high fat content, such as the liver after having been exposed to a fat-rich diet, prior lipid extraction is needed in order to avoid several issues, such as inappropriate chromatin fragmentation or low immunoprecipitation efficiency. The protocol described in this chapter has been optimised for ChIP assays on fresh (without a prior freeze) double crosslinked mouse steatotic (fatty) liver tissue. As an animal model of fatty liver, we have used adult C57BL/6J mice, fed a High Fat-High Cholesterol diet for 6 weeks, which has been previously shown to induce hepatic steatosis experimentally (9).

\section{Materials}

Prepare all solutions using ultrapure water and analytical grade reagents. Prepare and store all reagents at $4{ }^{\circ} \mathrm{C}$ or $-20^{\circ} \mathrm{C}$ as indicated (unless otherwise noted). Diligently follow all local waste disposal regulations when disposing of waste materials.

\subsection{Fatty liver mouse model}

1. 10 to 12 -week old wild-type C57BL/6J strain mice. 
2. High Fat-High Cholesterol (HFHC) Diet: $17.2 \%$ Cocoa Butter, $2.8 \%$ Soybean Oil, $1.25 \%$ Cholesterol, $0.5 \%$ Sodium Cholate.

3. 1x Phosphate Buffer Saline (PBS): $0.137 \mathrm{M} \mathrm{NaCl}, 0.0027 \mathrm{M} \mathrm{KCl}, 0.01 \mathrm{M}$ Na2HPO4, 0.0018 M KH2PO4. Filtered and stored at $4{ }^{\circ} \mathrm{C}$.

4. Dissection tools.

\subsection{Chromatin Immunoprecipitation}

1. $2 \mathrm{mM}$ disuccinimidyl glutarate (DSG) solution in PBS, room temperature.

2. Dimethyl sulfoxide (DMSO)

3. $1 \%$ formaldehyde in PBS.

4. $1.25 \mathrm{M}$ glycine solution, stored at room temperature.

5. 1x PBS, room temperature and cold.

6. Protease inhibitors cocktail: $2 \mathrm{mM}$ AEBSF, $0.3 \mu \mathrm{M}$ Aprotinin, $116 \mu \mathrm{M}$ Bestatin, 14 $\mu \mathrm{M}$ E-64, $1 \mu \mathrm{M}$ Leupeptin, 1 mM EDTA. Stock solution 1000x concentrated and stored at $-20^{\circ} \mathrm{C}$.

7. Dounce homogenizer.

8. $70 \mu \mathrm{M}$ cell strainers.

9. $1.5 \mathrm{~mL}$ microcentrifuge tubes.

10. $15 \mathrm{~mL}$ falcon tubes.

11. Rotating wheel.

12. Refrigerated centrifuge.

13. Scalpel or scissors.

14. Ice.

15. Cold room or similar.

16. Lysis Buffer 1 (LB1): 50 mM Hepes- $\mathrm{KOH}$ (pH 7.5), $140 \mathrm{mM} \mathrm{NaCl}, 1 \mathrm{mM}$ EDTA, $10 \%$ glycerol, $0.5 \% \mathrm{NP}-40,0.25 \%$ Triton X-100. Filtered and stored at $4{ }^{\circ} \mathrm{C}$.

17. Lysis Buffer 2 (LB2): $10 \mathrm{mM}$ Tris- $\mathrm{HCl}$ (pH 8.0), $200 \mathrm{mM} \mathrm{NaCl}, 1 \mathrm{mM}$ EDTA, 0.5 mM EGTA. Filtered and stored at $4{ }^{\circ} \mathrm{C}$.

18. Lysis Buffer 3 (LB3): 10 mM Tris- $\mathrm{HCl}$ (pH 8.0), $100 \mathrm{mM} \mathrm{NaCl}, 1 \mathrm{mM}$ EDTA, 0.5 mM EGTA, 0.1\% Na-Deoxycholate, $0.5 \% \mathrm{~N}$-sauroylsarcosine. Filtered and stored at $4{ }^{\circ} \mathrm{C}$.

19. Water-bath sonicator: e.g. UCD-300 Bioruptor (Diagenode).

20. $10 \%$ Triton $X-100$ solution in PBS.

21. $5 \mathrm{mM} \mathrm{NaCl}$.

22. Nuclease-free, molecular biology grade water.

23. Heating block.

24. RNaseA/T1 (2 mg/ml stock). 
25. Proteinase $\mathrm{K}(20 \mathrm{mg} / \mathrm{ml}$ stock).

26. $0.5 \mathrm{M}$ EDTA.

27. $1 \mathrm{M}$ Tris- $\mathrm{HCl}$.

28. DNA purification kit for fragments $100 \mathrm{bp}$ to $10 \mathrm{~kb}$ (eg. QIAquick PCR purification kit).

29. NanoDrop ${ }^{\mathrm{TM}}$ spectrophotometer.

30. Agarose.

31. Tris-Borate-EDTA (TBE) buffer: $0.089 \mathrm{M}$ Tris, $0.089 \mathrm{M}$ Boric Acid, $0.002 \mathrm{M}$ EDTA. Stored at room temperature.

32. DNA gel stain. (e.g. SYBR Safe).

33. Electrophoresis chamber and power supply.

34. Chromatin dilution buffer: 1\% Triton X-100, 2 mM EDTA, $150 \mathrm{mM} \mathrm{NaCl}, 20 \mathrm{mM}$ Tris- $\mathrm{HCl}(\mathrm{pH} 8.0)$. Filtered and stored at $4{ }^{\circ} \mathrm{C}$.

35. $50 \%$ slurry Protein A/G-Sepharose beads.

36. Sheared Salmon Sperm DNA (2 $\mathrm{mg} / \mathrm{mL}$ stock).

37. Bovine Serum Albumin (BSA) (2 mg/mL stock).

38. Antibody against protein of interest.

39. Immunoglobulin isotype control, same species as the immunoprecipitation antibody.

40. TSE buffer 1 (low salt wash buffer): $0.1 \%$ SDS, $1 \%$ Triton X-100, 2 mM EDTA, $150 \mathrm{mM} \mathrm{NaCl}, 20 \mathrm{mM}$ Tris- $\mathrm{HCl}\left(\mathrm{pH}\right.$ 8.0). Filtered and stored at $4{ }^{\circ} \mathrm{C}$.

41. TSE buffer 2 (high salt wash buffer): $0.1 \%$ SDS, $1 \%$ Triton X-100, 2 mM EDTA, $500 \mathrm{mM} \mathrm{NaCl}, 20 \mathrm{mM}$ Tris- $\mathrm{HCl}\left(\mathrm{pH}\right.$ 8.0). Filtered and stored at $4{ }^{\circ} \mathrm{C}$.

42. Wash buffer 3 (LiCl wash buffer): $0.25 \mathrm{M} \mathrm{LiCl}, 1 \% \mathrm{NP}-40,1 \%$ Deoxycholate, 1 $\mathrm{mM}$ EDTA, $10 \mathrm{mM}$ Tris- $\mathrm{HCl}(\mathrm{pH} 8.0)$. Filtered and stored at $4{ }^{\circ} \mathrm{C}$.

43. TE buffer: $10 \mathrm{mM}$ Tris- $\mathrm{HCl}\left(\mathrm{pH}\right.$ 8.0), $0.1 \mathrm{mM}$ EDTA. Filtered and stored at $4{ }^{\circ} \mathrm{C}$

44. Elution buffer: $1 \% \mathrm{SDS}, 0.1 \mathrm{M} \mathrm{NaHCO}_{3}$. Prepared fresh and kept at room temperature.

\section{Methods}

\subsection{Liver collection}

1. After 6 weeks of HFHC diet feeding, euthanize mice according to the relevant regulatory laws for animal experimentation. 
2. Carefully puncture diaphragm, cut the omemtum holding the liver to the stomach and the ligaments holding the liver to the kidneys. Remove the gall bladder when dissecting away the omemtum. Carefully cut the hepatic vein and remove liver.

3. Rinse liver in cold PBS.

\subsection{Crosslinking}

1. Weigh the freshly dissected liver and chop it in small pieces of approximate $5 \mathrm{~mm}$ diameter (see Note 1).

2. Immediately put the samples in freshly prepared DSG crosslinking medium (see Notes 2 and 3).

3. Rotate tubes for 30-45 minutes at room temperature.

4. Wash samples with $1 \mathrm{~mL}$ of room temperature PBS and centrifuge at $800 \times \mathrm{g}$, for 1 minute at room temperature. Remove all PBS.

5. Repeat the PBS washing step one more time (step 4).

6. Set up centrifuge to pre-cool to $4^{\circ} \mathrm{C}$ so that it is ready for step 9 .

7. Add $1 \%$ formaldehyde solution (see Note 3 ) and rotate tubes for 10 minutes at room temperature.

8. Quench formaldehyde by adding $1 / 10$ of $1,25 \mathrm{M}$ glycine solution and rotate for 5 minutes at room temperature (see Note 4).

9. Pellet the tissue pieces by centrifuging at $800 \times \mathrm{g}$, for 3 minutes at $4{ }^{\circ} \mathrm{C}$.

10. Wash three times with $1 \mathrm{~mL}$ cold PBS containing freshly added protease inhibitors by centrifuging at $800 \times \mathrm{g}$, for 3 minutes at $4{ }^{\circ} \mathrm{C}$ and discarding supernatant.

11. Grind the liver tissue pieces with a dounce homogenizer on ice.

12. Resuspend homogenates in $1 \mathrm{~mL}$ of cold PBS with freshly added protease inhibitors.

13. Pass the homogenized tissue suspension through a $70 \mu \mathrm{m}$ cell strainer to remove the connective tissue. 
14. Wash three times with $1 \mathrm{~mL}$ cold PBS with freshly added protease inhibitors (same as step 10).

15. At this point you can continue onto the next step (cell lysis) or freeze the pellet at $-80^{\circ} \mathrm{C}($ see Note 5$)$.

\subsection{Lysis}

2. Resuspend the cell pellet in $1 \mathrm{~mL}$ of Lysis buffer 1 (LB1) with freshly added protease inhibitors. Pipet up and down two to three times with $1000 \mu$ pipette tip until the pellet is disrupted and you have a suspension.

3. Leave the tube rotating for 10 minutes at $4^{\circ} \mathrm{C}$. Centrifuge the samples at $1000 \mathrm{x}$ $\mathrm{g}$ for 5 minutes at $4{ }^{\circ} \mathrm{C}$ and discard supernatant.

4. Resuspend the nuclei pellet in $1 \mathrm{~mL}$ of Lysis buffer 2 (LB2) with freshly added protease inhibitors. Pipet up and down until the pellet has disappeared and you have a suspension.

5. Leave the tube rotating for 5 minutes at $4{ }^{\circ} \mathrm{C}$. Centrifuge the samples at $1000 \times \mathrm{g}$, for 5 minutes at $4{ }^{\circ} \mathrm{C}$ and discard supernatant.

6. Resuspend the pellet in $300 \mu \mathrm{L}$ of Lysis buffer 3 (LB3) with protease inhibitors. Pipet up and down until the pellet is gone and you have a suspension.

7. Freeze the sample at $-80^{\circ} \mathrm{C}$ in LB3 so the sonication is facilitated (see Note 6 ).

\subsection{Sonication}

1. Cool down water bath first while samples are being frozen. Once water bath is cold, fit tubes inside the rotating wheel and set up sonicator to 40 cycles (30s ON +30 s OFF) on high setting (see Notes 7 and 8).

2. After sonication, add $30 \mu \mathrm{L}$ of $10 \%$ Triton $\mathrm{X}-100$ to the lysate. Centrifuge at $15,800 \times \mathrm{g}$ for $10 \mathrm{~min}$ at $4{ }^{\circ} \mathrm{C}$ to pellet debris. 
3. Transfer supernatant lysate to a fresh tube. You can use the chromatin directly (for immunoclearing) or freeze it at $-80^{\circ} \mathrm{C}$ (see Note 9). Keep $5 \mu \mathrm{L}$ of chromatin in a separate tube to test sonication efficiency (step 10).

\subsection{Sonication efficiency test}

Before proceeding with the chromatin immunoprecipitation, it is recommended to test sonication efficiency:

1. Reverse crosslink by mixing $5 \mu \mathrm{L}$ of chromatin (step 9) $+4 \mu \mathrm{L} \mathrm{NaCl} 5 \mathrm{M}+90 \mu \mathrm{L}$ molecular grade water in a $1.5 \mathrm{~mL}$ tube and leave overnight at $65^{\circ} \mathrm{C}$ in a heating block.

2. Add $2 \mu \mathrm{g}$ of RNaseA/T1. Mix and leave samples at $37^{\circ} \mathrm{C}$ for 30 minutes.

3. Add $20 \mu \mathrm{g}$ of Proteinase $\mathrm{K}+2 \mu \mathrm{l} 0.5 \mathrm{M}$ EDTA $+4 \mu \mathrm{l} 1 \mathrm{M}$ Tris- $\mathrm{HCl}$. Mix and leave samples at $55^{\circ} \mathrm{C}$ for 1 hour.

4. Purify DNA with DNA purification columns following the manufacturer's instructions and elute DNA in $40 \mu \mathrm{L}$ molecular grade water.

5. Check total DNA amount on a NanoDrop ${ }^{\mathrm{TM}}$ spectrophotometer or similar following manufacturer's instructions.

6. To visualise sonication products, run $20-30 \mu \mathrm{L}$ of purified DNA on a $1 \%$ agarose gel at $80 \mathrm{~V}$ for at least 30 minutes and visualise gel (see Note 10).

\subsection{Immunoclearing and chromatin immunoprecipitation}

1. Dilute the soluble chromatin in Dilution buffer with protease inhibitors in a $15 \mathrm{~mL}$ falcon tube: for one immunoprecipitation (IP) (1.1 mL final volume), add $800 \mu \mathrm{L}$ of dilution buffer to $300 \mu \mathrm{l}$ soluble chromatin (1 mL for each IP) (see Note 11).

2. Take $100 \mu \mathrm{L}$ into a fresh tube which will serve as a control input chromatin and leave at $4{ }^{\circ} \mathrm{C}$.

3. Prepare protein A/G-sepharose beads to a $50 \%$ final concentration in dilution buffer for $n+1$ the total number of samples you have. 
4. Perform immunoclearing to lower immunoprecipitation background by incubating soluble chromatin, rotating overnight at $4^{\circ} \mathrm{C}$ with: (see Note 12)

a. $2 \mu \mathrm{g} / \mathrm{mL}$ sheared Salmon sperm DNA

b. $2 \mu \mathrm{g} / \mathrm{mL}$ BSA

c. $45 \mu \mathrm{L}$ of Protein A/G-sepharose (50\% slurry)

5. Chill centrifuge at $4{ }^{\circ} \mathrm{C}$.

6. After immunoclearing, spin tubes at $300 \times \mathrm{g}$ for 2 minutes at $4{ }^{\circ} \mathrm{C}$ in a pre-chilled centrifuge and collect supernatant.

7. Aliquot pre-cleared samples in $1 \mathrm{~mL} / \mathrm{IP}$ in $1.5 \mathrm{~mL}$ tubes and add specific antibodies or IgG control (in a separate tube) (see Note 13).

8. Rotate tubes overnight at $4^{\circ} \mathrm{C}$.

\subsection{Wash, elution and reverse crosslinking}

1. Prepare the necessary volume of protein A/G-sepharose beads (50\% slurry) for all IPs (see section 3.4. step 3) in dilution buffer.

2. Add $60 \mu \mathrm{L}$ protein $\mathrm{A} / \mathrm{G}$-sepharose (50\% slurry) and $2 \mu \mathrm{g}$ of Salmon sperm DNA to each tube containing the chromatin and incubate while rotating for 2 hours at $4{ }^{\circ} \mathrm{C}$.

3. Pellet sepharose beads by centrifuging at $300 \mathrm{xg}$ for 1 minute at $4{ }^{\circ} \mathrm{C}$.

4. Carefully discard the supernatants containing non-bound chromatin without disrupting the sepharose pellet.

5. Wash the beads/antibody/chromatin complex, by adding $1 \mathrm{~mL}$ of each washing buffer, in the following order:

5.1. TSE I

5.2. TSE II

5.3. Buffer 3

5.4. TE Buffer (twice) 
For each buffer wash, rotate tubes for 10 minutes at $4{ }^{\circ} \mathrm{C}$, then harvest sepharose beads by centrifuging at $300 \times \mathrm{g}$ for 1 minute at $4{ }^{\circ} \mathrm{C}$. Carefully discard the supernatants containing non-bound chromatin without disrupting the pellet.

6. Prepare fresh Elution buffer.

7. Wash last time with $1 \mathrm{~mL}$ of cold PBS by pipetting only (no need to rotate tubes for 10 minutes) and remove as much PBS as possible after centrifugation. After this wash, bring centrifuge up to room temperature.

8. Add $100 \mu \mathrm{L}$ of Elution buffer and rotate 20 minutes at room temperature.

9. Spin down for 1 minute, $200 \times g$ at room temperature and collect eluates in a fresh tube.

10. Repeat steps 8 and 9 two more times, so that final volume of eluate is $300 \mu \mathrm{L}$.

11. Incubate eluates and input DNA (from step 3.4. section 2) overnight at $65^{\circ} \mathrm{C}$ to reverse crosslink.

12. Add $3 \mu \mathrm{L}$ of $2 \mathrm{mg} / \mathrm{mL}$ RNaseA to each tube. Mix and incubate at $37^{\circ} \mathrm{C}$ for $30 \mathrm{~min}$.

13. Add $3 \mu \mathrm{L}$ of $20 \mathrm{mg} / \mathrm{ml}$ Proteinase $\mathrm{K}$ to each tube. Mix and incubate at $55^{\circ} \mathrm{C}$ for 1 hour.

14. Purify DNA with DNA purification columns following the manufacturer's instructions and elute DNA in $50 \mu \mathrm{L}$ of $\mathrm{H} 2 \mathrm{O}$ (see Note 14).

15. Quantify enriched DNA by real-time quantitative PCR using specific primers amplifying the sequence and region of interest.

\section{Notes}

1. For fatty livers, a minimum amount of $75 \mathrm{mg}$ of tissue per preparation is recommended in order to obtain approximately $25 \mu \mathrm{g}$ of chromatin. However, hepatic lipid content will vary depending on experimental model and disease stage, so prior optimisation of initial tissue amount should be performed to ensure enough chromatin is isolated. 
2. DSG solution needs to be prepared fresh every time and excess should be discarded. In order to ensure proper solubilisation, first dissolve DSG in $100 \%$ DMSO to a concentration of $25 \mathrm{mM}$ and then further dilute in PBS to a final concentration of $2 \mathrm{mM}$.

3. For every $100 \mathrm{mg}$ of tissue, use $1 \mathrm{~mL}$ of DSG and $1 \%$ formaldehyde solutions.

4. Quenching of any non-bound formaldehyde molecules is crucial to avoid any downstream issues with sonication and should be performed in a timely manner. For every $1 \mathrm{~mL}$ of formaldehyde, add $100 \mu \mathrm{L}$ of $1.25 \mathrm{M}$ glycine solution.

5. It is recommended to perform double crosslinking on fresh tissue. Therefore, if needed, it is recommended to freeze after step 15 on section 3.5. and continue with the rest of the protocol at a later time.

6. Samples should be left to freeze at $-80^{\circ} \mathrm{C}$ for at least 1 hour.

7. This sonication conditions have been optimised for liver tissue and for this specific sonicator model. Optimisation of sonication conditions is strongly encouraged if using a different model or cell/tissue.

8. Sonicating for long periods of time can cause overheating. Make sure that the sonication water bath remains cold at all times by placing ice packs around it or by adding small amounts of ice inside the bath every 10 minutes.

9. Proteins and DNA are sensible to repeated freeze/thaw cycles, which can lead to their rapid degradation. Therefore, unless strictly needed, it is recommended to continue straight away with the next step after sonication.

10. Visualisation of sheared chromatin on an agarose gel is needed at least once in order to test sonication efficiency. A high efficiency is considered whenever most, if not all, DNA fragments are sized between 200 and $700 \mathrm{bp}$.

11. When diluting chromatin, calculate final volume as $1 \mathrm{~mL}$ per IP plus $100 \mu \mathrm{L}$ for input and add dilution buffer up to this final volume. For example, if diluting for 2 IPs, final volume is $2.1 \mathrm{~mL}$ and amount of dilution buffer that needs to be added to chromatin is $1.8 \mathrm{~mL}(2100-300=1800 \mu \mathrm{l})$. 
12. These amounts correspond to $1 \mathrm{IP}(1 \mathrm{~mL})$. If performing several IPs from the same chromatin preparation, immunoclearing should be performed in the same tube by multiplying the amounts of beads, salmon sperm and BSA by the number of IPs.

13. Amount of antibody needed should be optimised based on antibody specificity and amount of protein available in your sample. As an initial guide, ChIP antibodies are usually used from $1 \mu \mathrm{g}$ (for histone modifications) to $10 \mu \mathrm{g}$ (all other proteins) for every $25 \mu \mathrm{g}$ of chromatin.

14. For eluates, add 4 volumes of binding Buffer instead of $5(1.2 \mathrm{ml})$, in 2 turns $(600 \mu \mathrm{l}$ each). Note this will vary depending on the commercial column used to purify DNA fragments. Please refer to the manufacturer's instructions for the specific DNA purification column of your choice.

\section{REFERENCES}

1. Sever R and Glass CK (2013) Signaling by nuclear receptors. Cold Spring Harb Perspect Biol 5:a016709

2. Duarte J, Perrière G, Laudet V, et al (2002) NUREBASE: database of nuclear hormone receptors. Nucleic Acids Res 30:364-368

3. Gadaleta RM and Magnani L (2014) Nuclear receptors and chromatin: an inducible couple. J Mol Endocrinol 52:R137-149

4. Tian B, Yang J, and Brasier AR (2012) Two-step cross-linking for analysis of proteinchromatin interactions. Methods Mol Biol 809:105-120

5. Wagner M, Zollner G, and Trauner M (2011) Nuclear receptors in liver disease. 53:1023-1034

6. Baranello L, Kouzine F, Sanford S, et al (2016) ChIP bias as a function of crosslinking time. Chromosome Res 24:175-181

7. Sanyal AJ, Chalasani N, Kowdley K V., et al (2010) Pioglitazone, Vitamin E, or Placebo for Nonalcoholic Steatohepatitis. N Engl J Med 362:1675-1685

8. Neuschwander-Tetri BA, Loomba R, Sanyal AJ, et al (2015) Farnesoid X nuclear receptor ligand obeticholic acid for non-cirrhotic, non-alcoholic steatohepatitis (FLINT): a multicentre, randomised, placebo-controlled trial. 385:956-965

9. Matsuzawa N, Takamura T, Kurita S, et al (2007) Lipid-induced oxidative stress causes steatohepatitis in mice fed an atherogenic diet. 46:1392-1403 
